\title{
Development of Simulator and MPPT Algorithm for PEM Fuel Cell
}

\author{
S. Dharani \\ PG Student, Department of EEE, \\ SSN College of Engineering, \\ Chennai, India.
}

\author{
R.Seyezhai, PhD \\ Associate Professor, Department of EEE, \\ SSN College of Engineering, \\ Chennai, India.
}

\begin{abstract}
Now-a-days, many industries are starting to rely on the renewable energy sources as the alternate energy sources due to the hazardous emissions that can cause the negative consequences on the environment. An electrochemical device, Fuel Cell which produces electrical energy directly from the chemical energy is used. This paper discusses about PEM fuel cells due to their high efficiency and reliability among the several types of Fuel Cells. The mathematical model for 500W PEM Fuel Cell is developed and analyzed under static and dynamic conditions. Finally, transient response of PEM Fuel Cell is presented. For improving the efficiency of PEM Fuel Cell, MPPT algorithm is implemented.
\end{abstract}

\section{Keywords}

FC, PEMFC

\section{INTRODUCTION}

A fuel cell is a device that generates the electrical energy from the chemical energy through a chemical reaction with oxidizing agent. To produce electricity, a fuel cell combines hydrogen and oxygen. The similarity of battery and fuel cell is both convert the energy produced from chemical energy into a usable electric power. The difference between them is the fuel cell produces electricity as long as fuel is supplied and never losing its charge. The promising technology, the fuel cell is the source of heat and electricity for buildings and as an electrical power. The release of energy from the chemical reaction between hydrogen and oxygen is the basic principle of the fuel cell. At the anode of an electrolyte, the electrons are released by the ionization of hydrogen gas and $\mathrm{H}^{+}$ions are generated.

$2 \mathrm{H}_{2} \rightarrow 4 \mathrm{H}^{+}+4 \mathrm{e}^{-}$

At the cathode, the water is formed by the reaction among the oxygen, electrons from the electrode and $\mathrm{H}^{+}$ions from the electrolyte.

$\mathrm{O}_{2}+4 \mathrm{e}^{-}+4 \mathrm{H}^{+} \rightarrow 2 \mathrm{H}_{2} \mathrm{O}$

For the continuous reactions, electrons must transfer from the anode to the cathode through an electrical circuit and also $\mathrm{H}^{+}$ ions must transfer through the electrolyte.

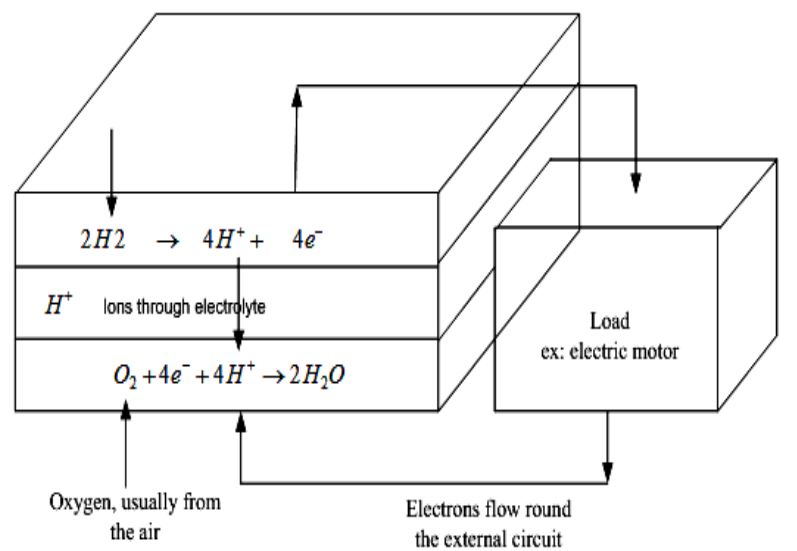

Fig 1: Reactions in the PEMFC

Figure 1 shows the electron and proton transfer flow of the PEMFC through load and through the electrolyte respectively.

\section{MATHEMATICAL MODELING OF PEMFC}

The static and dynamic model of PEMFC is developed for power generation application. The mathematical modeling is done by electrochemical equation that is based on the operational parameters of PEMFC. The selected model is simulated using MATLAB/SIMULINK and it is used to analyze the VI characteristics and transient response of the fuel cell.

\section{STATIC MODEL OF PEMFC}

The variation of the individual cell voltage is due to the various voltage drops in the fuel cell. The output voltage of a single cell can be defined as

$$
\mathrm{V}_{\mathrm{FC}}=\mathrm{E}_{\mathrm{Nerst}}-\mathrm{V}_{\mathrm{act}}-\mathrm{V}_{\mathrm{ohm}}-\mathrm{V}_{\mathrm{conc}}
$$

$\mathrm{E}_{\text {nerst }}$ represents the reversible voltage; $\mathrm{V}_{\text {act }}$ is the voltage drop due to the activation of the anode and cathode; $\mathrm{V}_{\mathrm{ohm}}$ is a measure of ohmic voltage drop; $V_{\text {conc }}$ represents the voltage drop resulting from the concentration or mass transportation of the reacting gases. For $\mathrm{n}$ cells connected in series and forming a stack, the voltage $\left(\mathrm{E}_{\mathrm{cell}}\right)$, can be calculated by:

$$
\mathrm{E}_{\mathrm{cell}}=\mathrm{nV}_{\mathrm{FC}}
$$

The ideal voltage is the maximum voltage that each cell in the stack can produce at a given temperature with the partial pressure of the reactants and products known. $\mathrm{E}_{\text {nerst }}$ equation is represented as

$\mathrm{E}_{\mathrm{Nerst}}=1.229-0.85 * 10^{-3}(\mathrm{~T}-298.15)+4.3085 *$
$10^{-5} \mathrm{~T}\left[\ln \mathrm{P}_{\mathrm{H}_{2}}+0.5 \ln \mathrm{P}_{\mathrm{O}_{2}}\right]$ 


\subsection{Activation Overvoltage}

The activation over voltage is the voltage drop due to the activation of anode and cathode .It can be calculated as:

$\mathrm{V}_{\mathrm{act}}=-\left[\xi_{1}+\xi_{2} \mathrm{~T}+\xi_{3} \mathrm{~T} \ln \left(\mathrm{C}_{\mathrm{O}_{2}}\right)+\xi_{4} \mathrm{~T} \ln \left(\mathrm{i}_{\mathrm{FC}}\right)\right.$

where $\xi$ i represents parametric coefficients for each cell model, whose values are defined based on theoretical equations with kinetic, thermodynamic, and electrochemical foundations . $\mathrm{C}_{02}$ is the concentration of oxygen in the catalytic interface of the cathode $\mathrm{mol} / \mathrm{cm}$, determined by

$\mathrm{C}_{\mathrm{O}_{2}}=\frac{\mathrm{P}_{\mathrm{O}_{2}}}{508 * 10^{6} \mathrm{e}^{(-498 / \mathrm{T})}}$

\subsection{Ohmic Voltage Drop}

This loss occurs due to the electrical resistance of the electrodes and the resistance to the flow of ions in the electrolyte. It is given by

$\mathrm{V}_{\text {ohmic }}=\mathrm{i}_{\mathrm{FC}}\left(\mathrm{R}_{\mathrm{m}}+\mathrm{R}_{\mathrm{c}}\right)$

where Rc represents the resistance to the transfer of protons through the membrane, usually considered constant and $R_{m}$ is

$\mathrm{R}_{\mathrm{m}}=\frac{\rho_{\mathrm{m}} \mathrm{l}}{\mathrm{A}}$

$\rho_{\mathrm{m}}$ is the specific resistivity of the membrane for the electron flow $(\mathrm{cm}), \mathrm{A}$ is the cell active area $\mathrm{cm}$ and 1 is the thickness of the membrane $(\mathrm{cm})$, which serves as the electrolyte of the cell.

\subsection{Concentration Loss}

This is due to the change in concentration of reactants at the surface of the electrodes as the fuel is used causing reduction in the partial pressure of reactants, resulting in reduction in voltage given by

$\mathrm{V}_{\text {con }}=-\mathrm{B} \ln \left(1-\frac{\mathrm{J}}{\mathrm{J}_{\max }}\right)$

The consumption of more fuel reduces the concentrations of hydrogen and oxygen at various points in the PEM fuel cell gas channels and increases the concentrations of these reactants at the input of the stack.

\section{DYNAMIC MODEL OF PEM FUEL CELL}

Under sudden change in load current, the dynamic model is used to predict the transient response of the cell voltage, hydrogen/oxygen outflow rate and cathode and anode channel temperatures/pressures. In this model, the charge double layer capacitance is a function of the electrode and individual stack properties. The voltage formed due to this charge double layer will take some time to respond to sudden change in the current. When the current is increased by sudden increase in the load, there is an immediate drop in the output voltage due to the ohmic resistance of the cell. The equivalent circuit for the PEMFC is shown in the figure 2 based on the consideration of the capacitive effect.

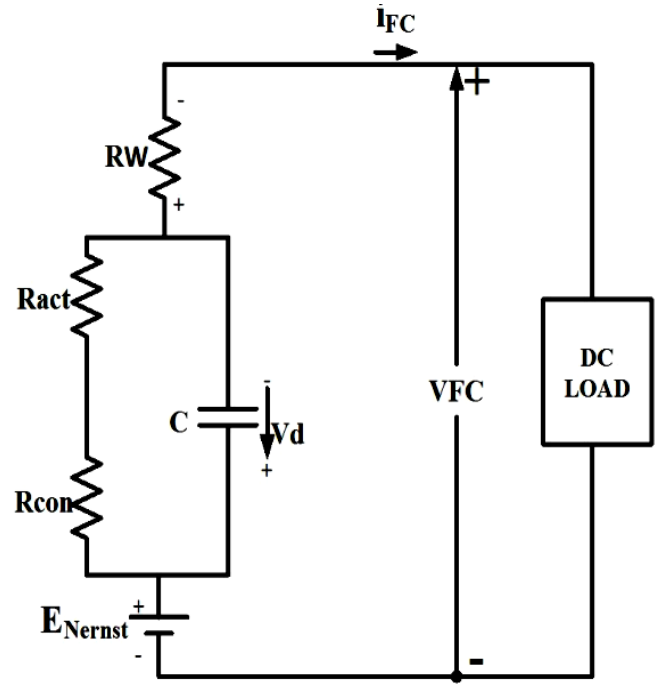

Fig 2: Equivalent cirucit for PEMFC

where $\mathrm{R}_{\mathrm{w}}, \mathrm{R}_{\text {act }}$ and $\mathrm{R}_{\text {con }}$ are ohmic,activation and concentration resistance respectively and $C$ is the capacitance due to double layer effect. The dynamic behaviour is based on the following equations

$\mathrm{P}_{\mathrm{H} 2}=\frac{\frac{1}{K_{H_{2}}}}{1+\tau_{H_{2} S}}\left(q^{i n} H 2-2 K_{r} I\right)$

$\mathrm{P}_{\mathrm{o} 2}=\frac{\frac{1}{K_{o_{2}}}}{1+\tau_{o_{2} S}}\left(q^{i n} o 2-K_{r} I\right)$

where $\mathrm{P}_{\mathrm{H} 2}, \mathrm{P}_{\mathrm{o} 2}$ represents partial pressure of hydrogen and oxygen, $\mathrm{q}_{\mathrm{H} 2}, \mathrm{q}_{\mathrm{o} 2}$ represents flow rate of hydrogen and oxygen, $\mathrm{K}_{\mathrm{r}}$ is constant and $I$ is the stack current.

\section{MPPT ALGORITHM FOR PEM FUEL CELL}

In order to improve the efficiency of the PEMFC generation system, PEMFC stack should be controlled to generate maximum power with optimization of the fuel consumption. In most situations, it is actually undesirable to operate at a maximum power because normally the fuel efficiency is at best $50 \%$. By applying MPPT, the situation can be solved because MPPT aims at reaching the MPP at different fuel flow rates. Due to its simplicity, the $\mathrm{P} \& \mathrm{O}$ algorithm is the most commonly used MPPT method. Figure 3 shows the flow chart for P\&O MPPT algorithm. In the P\&O MPP algorithm, the principle is to provoke perturbation by altering the PWM duty cycle command and observe the PEMFC's output to operate near the maximum point. If the power increases due to perturbation then the perturbation will remain in the same direction or otherwise it is reversed. 
Table :1 Simulation parameters for Fuel Cell

\begin{tabular}{|c|c|}
\hline Parameters & Values \\
\hline$\Delta \mathrm{G} / 2 \mathrm{~F}$ & 1.229 \\
\hline$\Delta \mathrm{S} / 2 \mathrm{~F}$ & $0.85 \mathrm{e}-3$ \\
\hline $\mathrm{RT} / 2 \mathrm{~F}$ & $4.3085 \mathrm{e}-5$ \\
\hline $\mathrm{T}$ & $333 \mathrm{~K}$ \\
\hline $\mathrm{T}_{\text {Ref }}$ & $298.15 \mathrm{~K}$ \\
\hline$\varepsilon_{0} 1$ & -0.948 \\
\hline$\varepsilon_{6}^{2}$ & $0.00286+0.0002 \ln (\mathrm{A})+0.000043 \ln \left(\mathrm{C}_{\mathrm{H} 2}\right)$ \\
\hline$\varepsilon 3$ & $7.6 e-5$ \\
\hline$\varepsilon_{6}^{4}$ & $-1.93 \mathrm{e}-4$ \\
\hline $\mathrm{A}$ & $65 \mathrm{~cm}^{2}$ \\
\hline $\mathrm{R}_{\mathrm{c}}$ & $3 \mathrm{e}^{-4} \Omega$ \\
\hline$\phi$ & $20(14$ to 23$)$ \\
\hline $\mathrm{L}$ & $178 \mu \mathrm{m}$ \\
\hline B & $0.016 \mathrm{~V}$ \\
\hline $\mathrm{J}_{\max }$ & $0.7 \mathrm{~A} / \mathrm{cm}$ \\
\hline $\mathrm{K}_{\mathrm{H} 2}$ & $4.22 \mathrm{e}-5 \mathrm{kmol} / \mathrm{s} . \mathrm{atm}$ \\
\hline $\mathrm{K}_{\mathrm{o} 2}$ & $2.11 \mathrm{e}-5 \mathrm{kmol} / \mathrm{s} . \mathrm{atm}$ \\
\hline $\mathrm{K}_{\mathrm{r}}$ & $1.0364 \mathrm{e}-5 \mathrm{kmol} / \mathrm{s} . \mathrm{A}$ \\
\hline $\mathrm{P}_{\mathrm{H} 2}$ & 1atm \\
\hline $\mathrm{P}_{\mathrm{O} 2}$ & $0.2095 \mathrm{~atm}$ \\
\hline
\end{tabular}

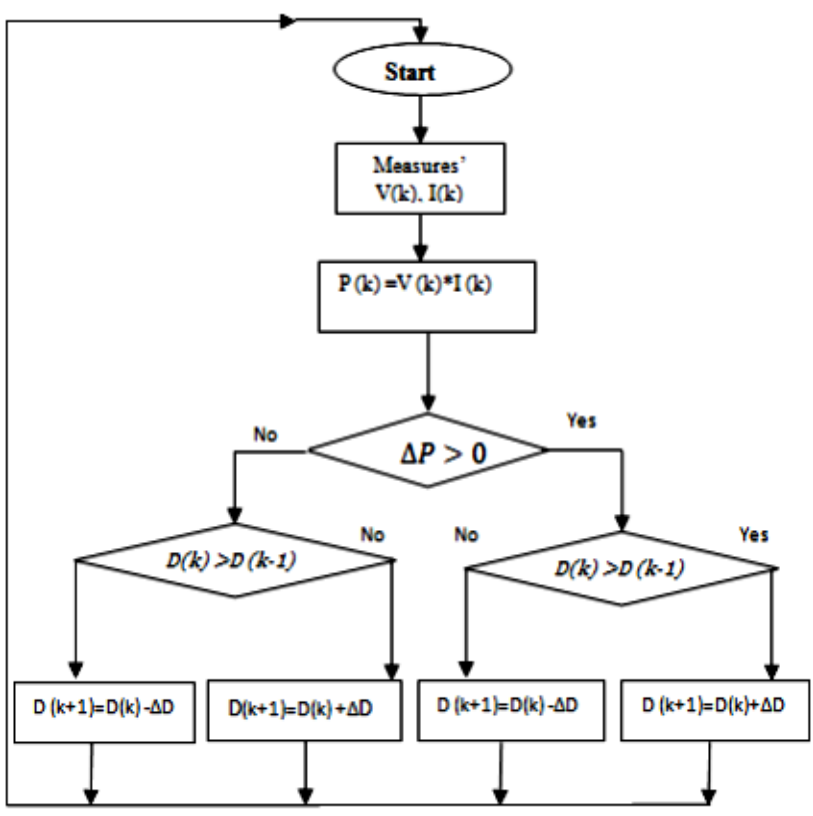

Fig 3: Flow Chart for P\&O MPPT

\section{FUEL CELL SIMULATOR}

Fuel cell simulator is developed by using PEM fuel cell equivalent circuit. FC simulators are a key role in the development of FC power electronics. The main reasons of a FC simulator are the cost of FC stacks, startup time, hydrogen storage, and other considerations such as facilities and safety standards. In order to run a FC stack, additional equipment is required (tanks, pumps, pressure regulator, etc). The size of the auxiliary equipment is related to the size of the FC stack and the associated cost and space can be excessive. Thus, flexible affordable FC simulators are required to assist the development and testing of FC power electronics.

\section{SIMULATION RESULTS}

By using MATLAB for mathematical modeling, the VI characteristic is obtained for the following values as in the table1. The number of cells connected in series is varied based on the requirement of the voltage values.

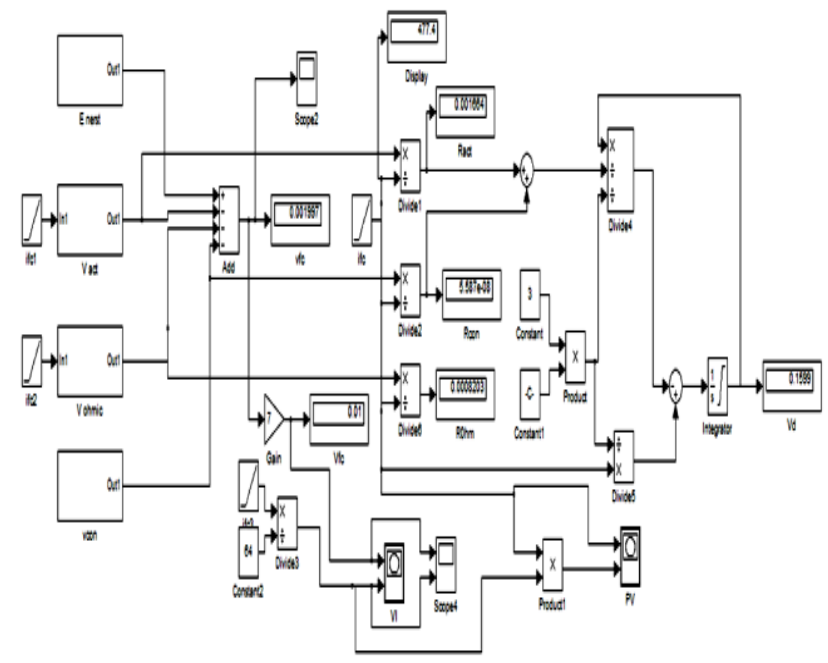

Fig 4: Static model of PEMFC 
Using the mathematical equations and values, the fuel cell is modeled and the simulink model is shown in the fig. 4. The transient behaviour is obtained by using the the dynamic model of PEMFC as shown in the fig. 5.

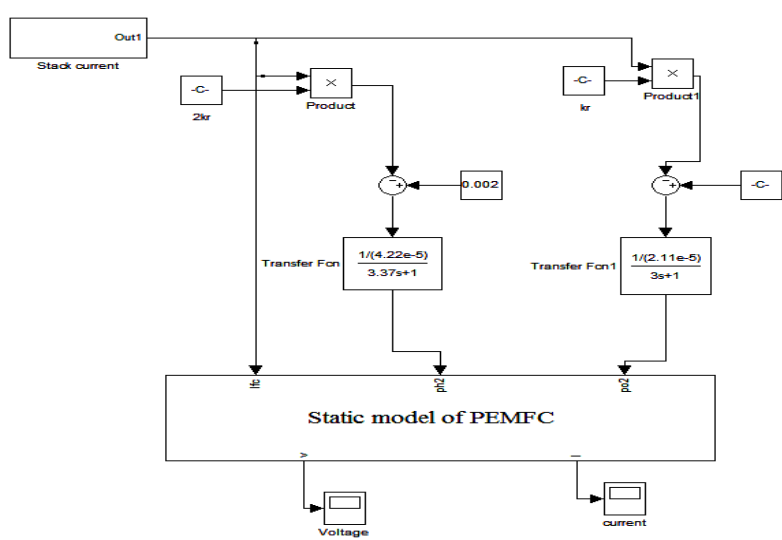

Fig 5: Dynamic model of PEMFC

The VI characteristic is obtained by modeling and voltage versus current density and power versus current density are shown in the figure 6 for $500 \mathrm{~W}$ power. Figure 6(a) shows waveform for individual fuel cell of $0.6 \mathrm{~V}$.

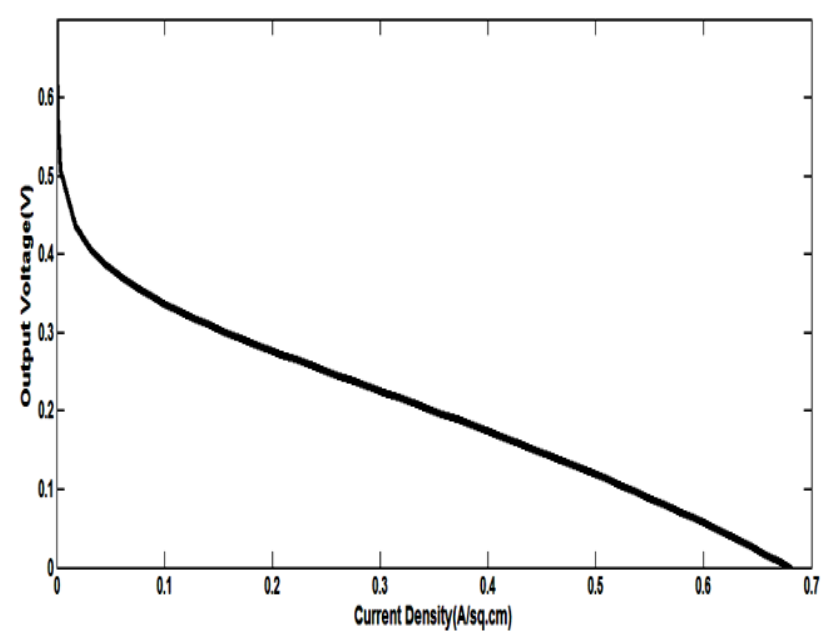

Fig 6(a): Individual cell voltage

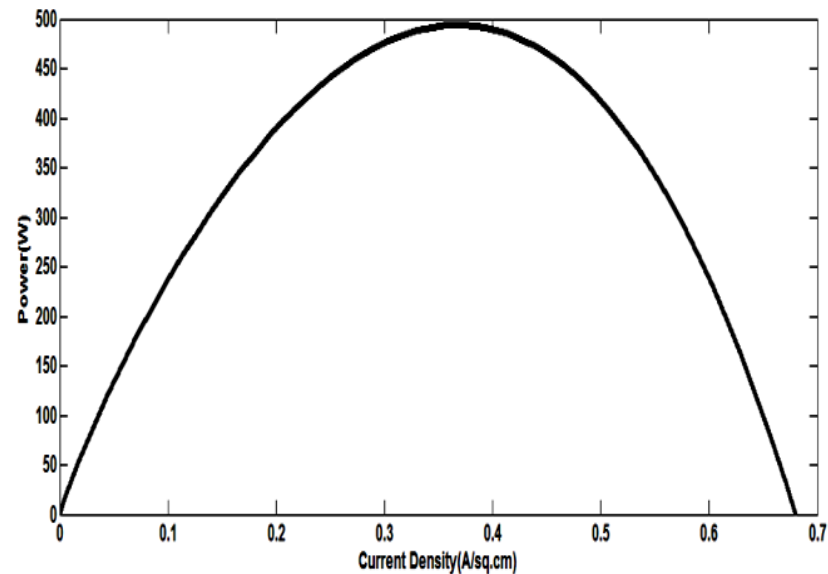

Fig 6(b): Power Vs Current Density
Figure 7 shows the variable voltages by varying the number of fuel cells. By using 10, 20 and 40 fuel cells, the voltages of $6 \mathrm{~V}$, $12 \mathrm{~V}$ and $24 \mathrm{~V}$ are produced.

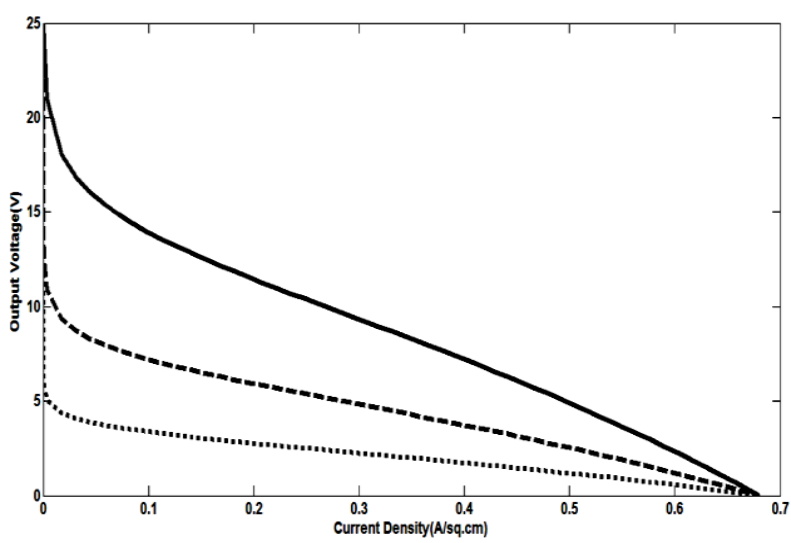

Fig 7: Output Voltages for fuel cell stack

The transient response of the PEMFC is shown in the figure 8. It can be observed that the output voltage is dropped and current increased when the load is increased.
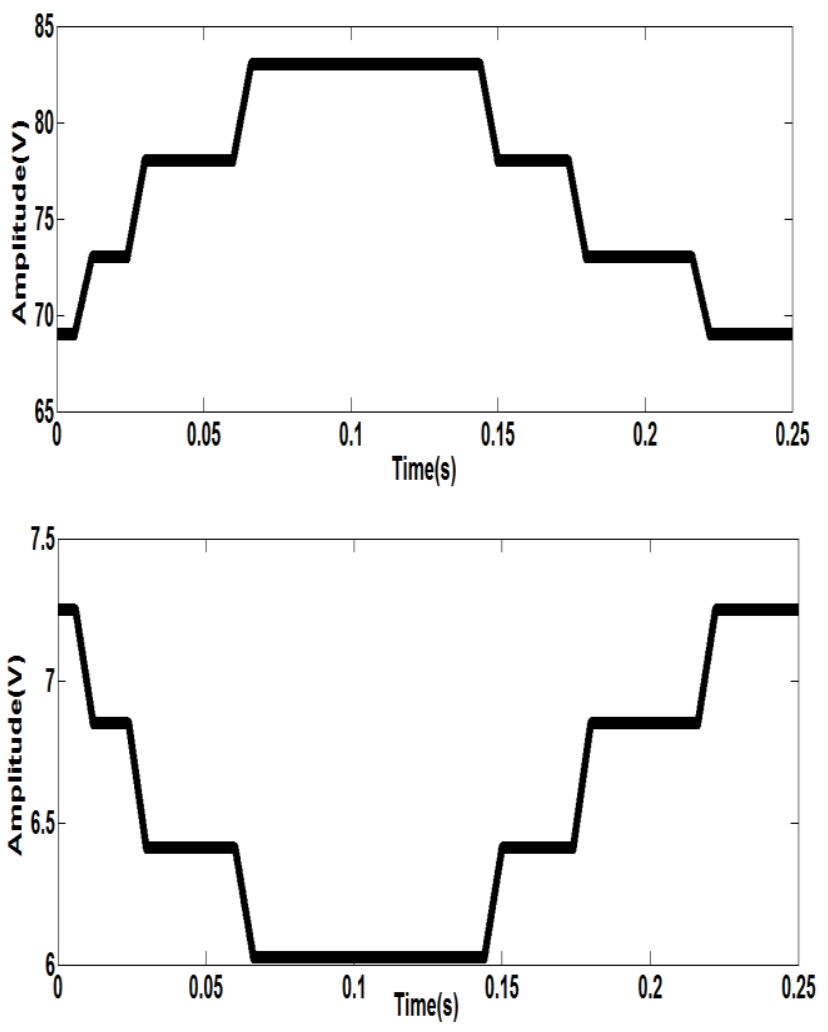

Fig 8: Transient response of PEMFC

The MPPT unit is used for fuel optimization technique. The simulink model for P\&O MPPT is shown in the fig. 9. 


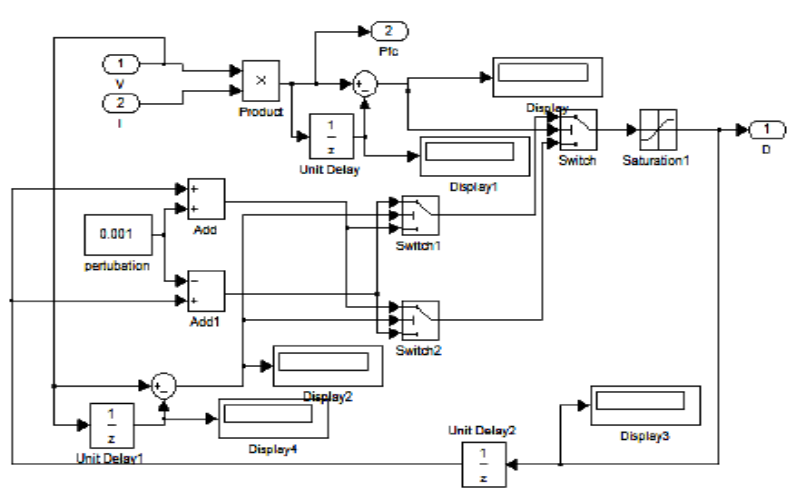

Fig 9: P\&O MPPT

The fuel cell simulator for $6 \mathrm{~V}$ is developed by using equivalent circuit of FC and it is shown in the figure 11. The output voltage obtained is shown in the figure 12

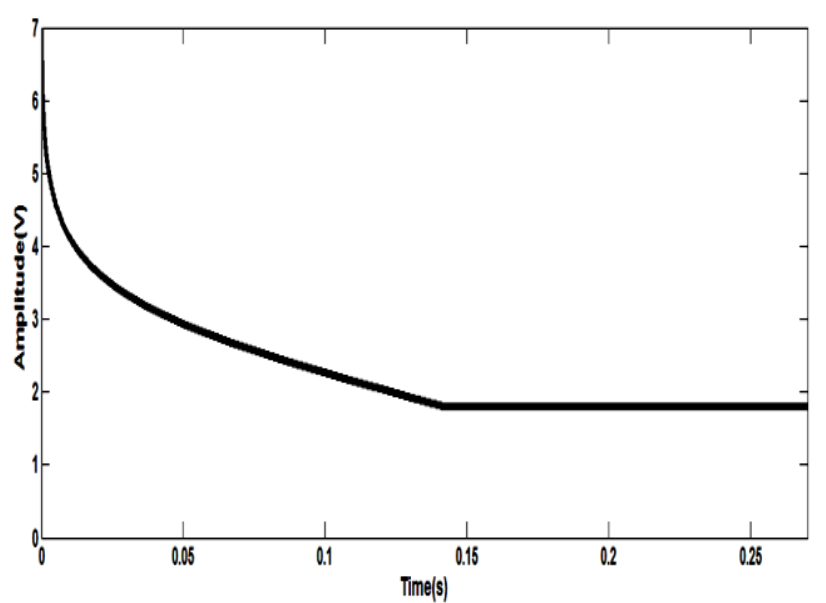

Figure 10: MPPT Output for 6V PEMFC

The output obtained from MPPT unit for $6 \mathrm{~V}$ fuel cell is shown in the figure 10.

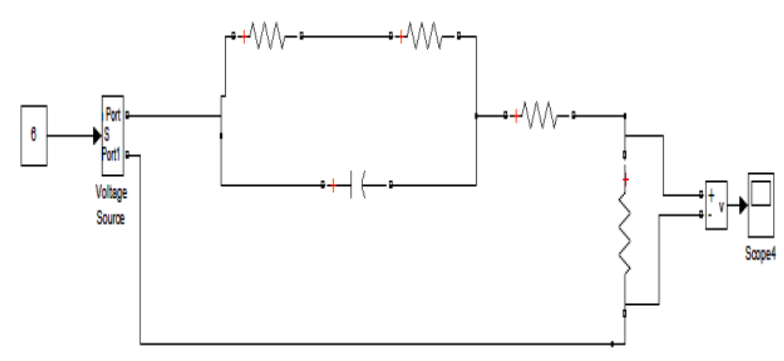

Figure 11: Fuel Cell Simulator

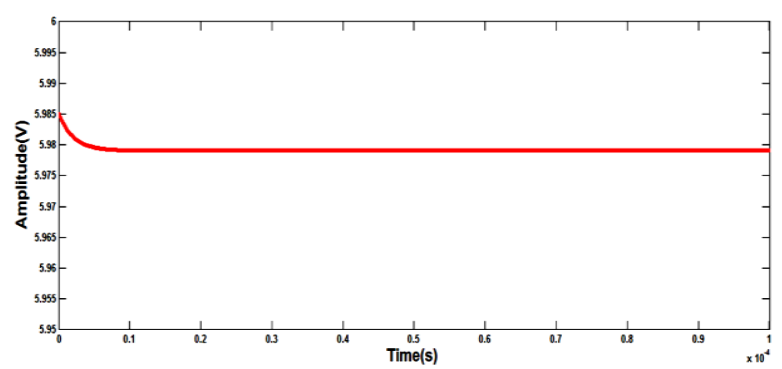

Figure 12: Output voltage of FC simulator

\section{CONCLUSION}

In this paper, mathematical model is developed to simulate static and dynamic response of PEMFC. The VI characteristics of the fuel cell are obtained for different voltages. By using the electrochemical equations, the dynamic response is analyzed. The transient response of the fuel cell is used in the application of power generation. The maximum power is achieved by using $\mathrm{P} \& \mathrm{O}$ MPPT technique. The flexible fuel cell simulator is developed by considering its equivalent circuit.

\section{ACKNOWLEDGEMENT}

The authors wish to thank the SSN Management for providing the financial support in carrying out this research work.

\section{REFERENCES}

[1] Xu Qingshan, Whang niachum, Kazuto yuhito (2012), 'PEM fuel cell modeling and parameter influences of perfomance evaluation', journal of school of electrical engineering southeast university-Nanjing Vol 70,pp 515527.

[2] D. Yu and S. Yuvarajan, "A novel circuit model for PEM fuel cells," in Proc. Appl. Power Electron. Conf. Expo., vol. 1, 2004, pp. 362-366

[3] Zambri.N.A, A. Mohamed, H. Shareef, and M. Z. C. Wanik (2013), 'Design of Hybrid Fuel Cell with Battery Energy Storage for Stand-Alone Distributed Generation Applications', World Academy of Science, Engineering and Technology Vol:7 2013-06-20

[4] Ozpineci.B, L. M. Tolbert, Zhong Du(2004), 'Optimum fuel cell utilization with multilevel inverters', in Proc. IEEE $35^{\text {th }}$ Power Electronics Specialist Conference, PESC'04, Vol.6, pp. $4798-4802$.

[5] Yerramalla, A. Davari, and A. Feliachi, "Dynamic modeling and analysis of polymer electrolyte fuel cell," in Proc. IEEE Power Eng. Soc. Summer Meeting, vol. 1, Jul. 2002, pp. 82-86.

[6] Wang.Y, Wang .C., "Transient analysis of polymer electrolyte fuel cells", Journal of power sources,2005, pp.1307-1315

[7] Friede W., Rael S., Davat B.(2004), 'Mathematical model and characterization of the transient behavior of a PEM fuel cell', IEEE Transactions on Power Electronics,Vol. 19, Issue 5, pp. 1234-1241.

[8] Pasricha.S. Keppler.M., Shaw.S.R., and Nehrir.M.H. "Comparison and identification of static electrical terminal fuel cell models", IEEE Trans. on Energy Conversion,2007, vol.22, pp.746 -754Correa,

[9] N.A. Zambri, A. Mohamed, and H. Shareef, "Performance comparison of dynamic models of proton exchange membrane and planar solid oxide fuel cells subjected to load change,"IREMOS., vol. 4 no. 6, pp. 3402-3409, December 2011

[10] Ch Rambabu, M Sunil Kumar And N Sri Harish(2012), 'Design Of MPPT Based Hybrid Wind And Fuel-Cell Energy System', International Journal Of Computer Science \& Communication Networks, Vol 1(3), pp.297-304

[11] N. Femia, G. Petrone, G. Spagnuolo and M. Vitelli,, “ Optimization of perturb and observe maximum power point tracking method,"IEEE Trans. Power Elect.,vol. 20, pp. 963-973, July 2005. 
[12] J.M.,Farret, F.A.,Canha, L.N., Simoes,M.G. (2004) , 'An Electrochemical based fuel cell model suitable for electrical engineering automation approach', IEEE Trans. on Industrial Electronics, Vol 51, Issue 5, pp.1103-1112

[13] M.H. Nehrir, C. Wang, and S.R. Shaw, "Fuel cells: promising devices for distributed generation,'IEEE Power and Energy Magazine, vol. 4,pp. 47-53, Jan-Feb 2006.

[14] R. Marouani, and F. Bacha, "A maximumpowerpointtracking algorithm applied to a photovoltaicwater-pumping system,"'Proceeding of the 8thInternational Symposium AdvancedElectromechanical Motion Systems and ElectricDrives Joint Symposium, vol. 1, pp: 1-6, Sept. 2009.

[15] M.Y.El-Sharkh, A.Rahman, M.S.Alam, P.C.Byrne, A.A. Sakla, and T.Thomas, "A dynamic model for a stand-alone PEM fuel cell power plant for residential applications,"J. Power Sources, vol. 138, pp. 199-204, November 2004. 